\title{
2017 APSA Ralph Bunche Scholars Present iPosters
}

$\mathrm{B}$ enefitting from work completed at the 2017 Ralph Bunche Summer Institute, seven RBSI scholars presented their research in several iposter sessions, sponsored by Cambridge University Press, at the Annual Meeting:

Sydney Carr, University of Connecticut, "Where are all the Women at in Congress?: An Analysis of the Lack of Female Political Representation in the US"

Rebecca Gonzalez, Temple University, "The Intersections of Latino Identity: Religion, Group Consciousness, and Immigration Policy"
Joan Joseph, Florida State University, "Institutional Persistence: Colonial Legacies and Corruption"

Monique Newton, Oberlin College, "Everything's Corrupt: Evaluating Perceptions of Corruption and Voter Turnout in the United States"

Avery Pearl, Augustana College, "Black Perceptions Towards the Black Lives Matter Movement"

Rodolfo Solis, Wabash College, "Intergroup Interaction and its Effect on Public Opinion"

Angie Torres, University of Central Florida, "Voter Sensibility to Terrorism in the United States" -

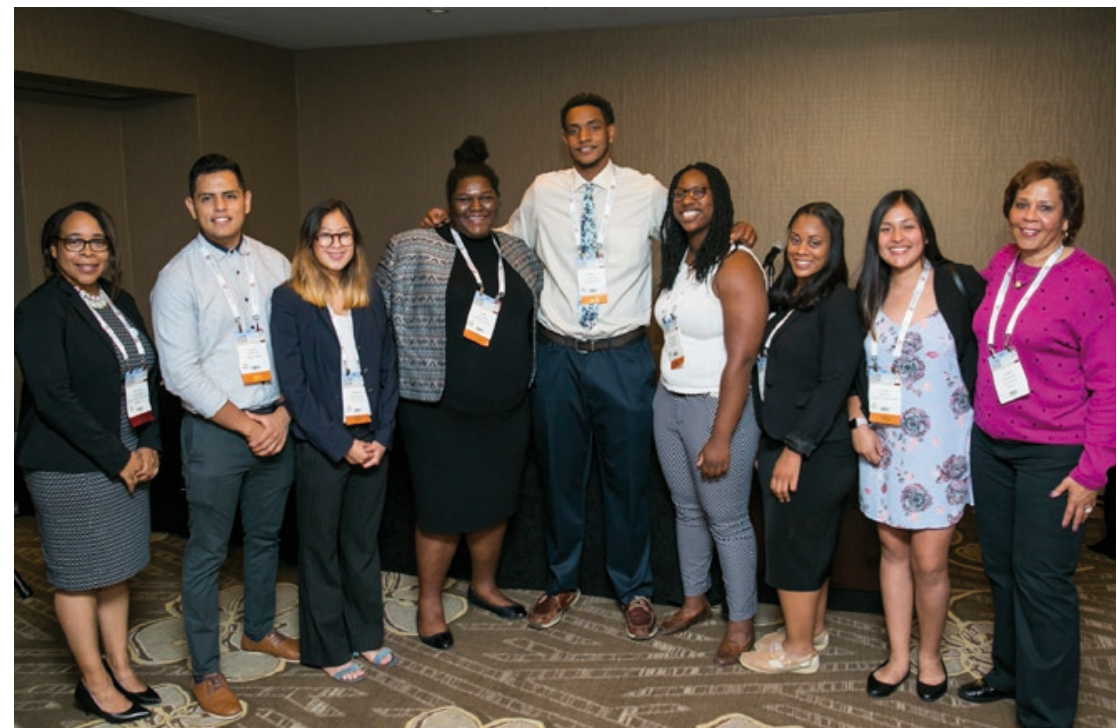

Kimberly Mealy, Senior Director of Diversity \& Inclusion, APSA, with some 2017 Ralph Bunche Summer Institute scholars ( $L$ to R) Rodolfo Solis, Wabash College, Rebecca Gonzalez, Temple University, Joan Joseph, Florida State University, Avery Pearl, Augustana College, Monique Newton, Oberlin College, Sydney Carr, University of Connecticut, Angie Torres, University of Central Florida, as well as RBSI Director Paula D. McClain, Duke University.

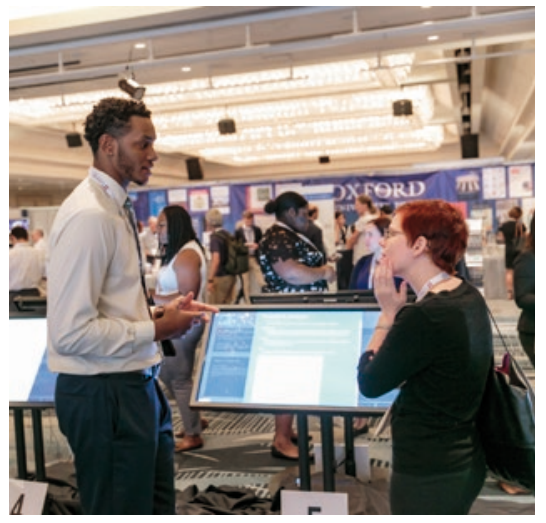

Avery Pearl, Augustana College, discusses his research on "Black Perceptions Towards the Black Lives Matter Movement."

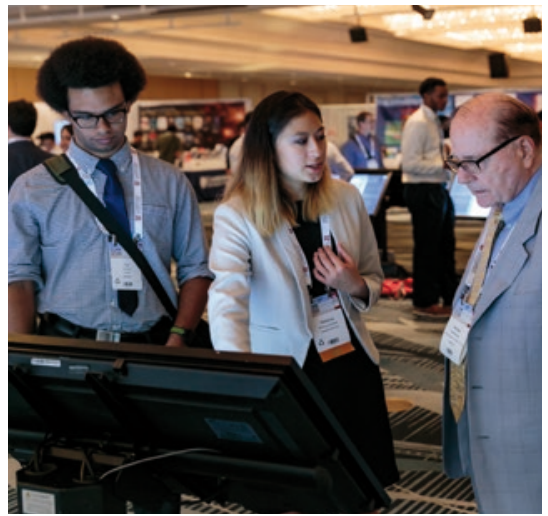

Rebecca Gonzalez, Temple University, discusses her iposter on "The Intersections of Latino Identity: Religion, Group Consciousness, and Immigration Policy."

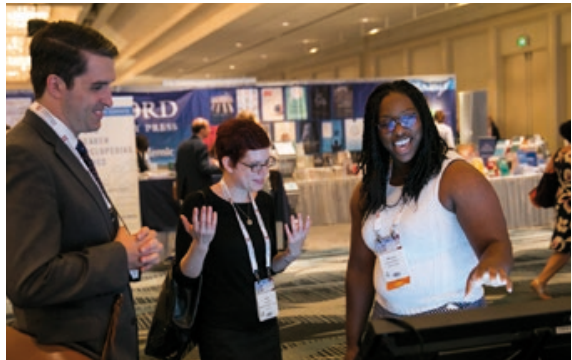

Monique Newton, Oberlin College, walks attendees through her research in her iposter presentation.

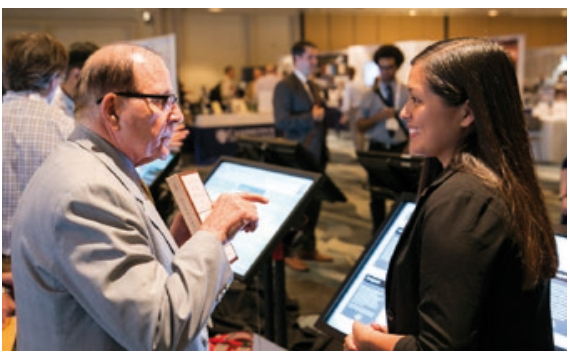

Angie Torres, University of Central Florida, explains her research to an annnual meeting attendee. 